\title{
Scaling of Mood-State and Sample Cases Causing Anger in a Relationship with Rank-Order Judgment and Classifying Judgment
}

\author{
Merve Yildirim Seheryeli (D)1,*, Duygu Anil (iD)2
}

${ }^{1}$ Hasan Kalyoncu University, Faculty of Education, Gaziantep, Turkey

${ }^{2}$ Hacettepe University, Faculty of Education, Ankara, Turkey

\section{ARTICLE HISTORY}

Received: 10 November 2019

Revised: 11 February 2020

Accepted: 06 March 2020

\section{KEYWORDS}

Anger in a relationship,

Scaling techniques,

Rank-order judgment,

Classifying judgment,

Measurement of affective features

\begin{abstract}
This study is a survey study which aims to determine underlying causes of anger and the anger levels of individuals, in the sample cases and mood-states defined in the research. 255 people participated by filling in forms developed by the researcher. They were asked to rank 6 mood-state expressions between 1 and 6, to classify 23 sample case expressions between 1 and 4. Using Microsoft Office Excel 2016, responses given to mood-state expressions were examined with rank-order and given to sample case expressions were examined with classifying judgment with respect to gender and marital status. The findings of rank-order judgment scaling revealed that all participants get angry most when they are treated unfairly and they get angry least when they are criticized. It was also found that females got angry more at being neglected, and males got angry more at arrogance and mistrust. It was concluded that married people got angry more at being neglected; unmarrieds got angry more at mistrust. The findings of classifying judgment scaling showed that all participants get angry the most when unnecessary and offending comments are made about their families. They get angry the least when their partners are fan of any subject. It also has been seen that married participants chose 'Ignoring the subjects that I care about' the most and those who are unmarried chose 'Making unnecessary and offending comments about my family' the most.
\end{abstract}

\section{INTRODUCTION}

When the other drivers do not obey the traffic rules while we obey the rules; when drivers go on picking up passengers on a fully loaded bus in public transportation; when our children do not listen to us or our boss mobbing us; when our parents do not allow us to do something or our partner does not pack his/her socks; when our teacher gives us a low mark or the person that we love does not love us, when we can't express ourselves sufficiently or when we experience the worst things all the time or while watching the evening news, we respond with one of our basic feelings: anger.

Anger is "a natural reaction to unsatisfied wishes, undesirable results and unmet expectations". Anger, which works as a self-protection mechanism as long as the degree of this reaction is favorable, becomes dangerous when it turns into a deep hatred and aggression. Domestic violence, abuse, harassment, terrorism and murder etc. can be shown as examples of

CONTACT: Merve YILDIRIM SEHERYELI $\bigotimes$ yldrm.mrv.7806@gmail.com Sciences, Faculty of Education, Hasan Kalyoncu University, Gaziantep, Turkey

Department of Educational 
situations that anger turns into danger. Therefore, to accept without denial, express in a controlled manner without suppressing it, understanding the reasons and restricting them can help the feeling of anger become favorable and effective before it turns into destructive behaviors (Soykan, 2013).

Many studies indicate that anger is not planned and it generally occurs as a result of basic painful feelings such as offence, resentment, rejection, fear, anxiety, frustration, being treated unfairly, criticism and humiliation (Balkaya, 2001; Balkaya \& Şahin, 2003; Satıc1, 2014). It becomes easier to deal with this feeling when the reasons of anger are understood and situations that cause anger are noticed. Soykan (2013) explained why we should deal with anger as follows:

- Anger causes a lot of social and individual problems such as verbal, physical violence, abuse etc. and it gives rise to serious problems in interpersonal relations in work and family life.

- As a result of not being able to overcome anger, it leads to mental problems like avoiding social life, addiction to smoking/drugs, eating disorders and depression.

- Anger that is not expressed in appropriate ways triggers physical problems as cardiovascular disease, immune and excretory system discomfort.

In her thesis study, Balkaya (2001) developed Multidimensional Anger Scale and included the dimension of anger eliciting situations in addition to the dimensions which are symptoms of anger, anger reactions, anger related cognitions and interpersonal anger. However, she tried to reveal the differences/resemblances between anger and furiousness.

In their study, Balkaya \& Şahin (2003) conducted a scale development study that discusses anger as a multidimensional issue. They included the dimension of anger eliciting situations together with the dimensions which are symptoms of anger, anger reactions, anger related cognitions, and interpersonal anger. Yet, these situations remained restricted to not being taken seriously, being treated unfairly and being criticized.

When the literature was examined, it was found that Erdoğdu (2018), Kırdök (2017), Uğurcan (2018), and Yapabaş (2018) investigated the relations between anger level, anger management style and different variables (stress, depression, alexithymia, eating behaviors, codependency, early adaptation schemas) in their thesis studies.

Although anger mostly seems to be a feeling towards people who we do not like, in their study Kassinove \& Suckodolsky (1995) has found that people get angry with the people they like most or the people they know, then they get angry with the people they do not know, and they get angry the least with the people that they dislike.

The reason why people get angry with the people they like most or the people they know is due to individual differences such as culture, education and perspective, between the people they communicate with most. Kaynak (2014) states that because couples are in constant interaction, their conflict areas increase, so anger is frequently experienced. However, he stated that the reactions of males and females to anger are also different. In most of the studies mentioned above, it has been pointed out that anger differentiates according to gender.

In interpersonal and romantic relationships or in marriage, while anger should be perceived as an individual difference, it is regarded as a war that must be won. Hence, many couples show behaviors like ignoring conflicts, denial, avoiding facing with each other, as they do not know how to cope with anger (Özmen Süataç, 2010). As a result of this, marital satisfaction and harmony and interpersonal communication get weaker, so it causes couples to give up on each other (Erok, 2013; Togay, 2016). 
Psychological features, like feelings that cannot be observed directly and cannot be represented with physical magnitude, are tried to be defined as the way people perceive them. Psychophysics is the science that reveals the relationship between the measured (physical dimension) and perceived (psychological dimension) magnitude of these stimulants.

In this psychological dimension, there are no defined units or scales of the variables. Therefore, attempts to estimate the relations with least error led to scaling methods (Turgut \& Baykul, 1992). Two different methods are used in scaling. In judgment method observers or experts scale stimulants in one dimension by identifying the location of each stimulant according to the other stimulant, whereas in response method the people that give response, not as experts but as subjects who give their own judgments, determine the location of stimulant according to its own location in scaling dimension (An1l \& Güler, 2006).

There are different types of scaling methods such as pair wise comparison (Güler \& Anıl, 2009; Güvendir \& Özer-Özkan, 2013; Yılmaz Koğar \& Demircioğlu, 2016), ranking (Özkan \& Arslantaş, 2013; Bozgeyikli, Toprak \& Derin, 2016; Yaşar, 2016), classifying (Demirus \& Gelbal, 2020; Güvendir \& Özer-Özkan, 2013; Sayın \& Gelbal, 2014), absolute judgment method (Tezbaşaran, 2017), summated rating scale and multidimensional scaling (Bülbül \& Köse, 2010; Tüzüntürk, 2009). Although the studies conducted show that only one scaling method has been used, Acar Güvendir \& Özer Özkan (2013), Albayrak Sarı \& Gelbal (2015) have used pair wise comparison and rank-order judgment scaling methods together in their studies. In this study, both rank-order judgment and classifying judgment scaling will be used.

In order to carry out measurement process, a well-defined structure and operational definition of this structure are needed (Crocker \& Algina, 2006). However, a need for bridge between psychological and physical space arise when it comes to the measurement of complex structures as feelings.

In this study, it was aimed to scale situations eliciting anger in individuals who are in a relationship. In accordance with this aim, rank-order judgment and classifying judgment scaling methods were used in order to investigate how mood-states and sample cases causing anger were ranked and to study the difference in this ranking. Research questions of the study are as follows:

1.How are the scale values and ranking of mood-states causing anger in males and females?

2. How are the scale values and ranking of mood-states causing anger in married participants and unmarrieds?

3. How are the scale values and ranking of sample cases causing anger in males and females?

4. How are the scale values and ranking of sample cases causing anger in married participants and unmarrieds?

By means of responses given to these research questions, it was intended to determine the reasons that individuals in a relationship (married or unmarried) feel angry most or least with a method different from the literature. It is considered that understanding the reasons behind anger will decrease the conflicts, and couples' desire to understand each other and maintain a relationship will contribute to relationship satisfaction.

\section{METHOD}

In this section, data analysis is explained by giving information about research model, study group, and data collection tools.

\subsection{Research Model}

In this study, it was aimed to scale responses to the situations eliciting anger in a relationship, given by the individuals who are married, engaged or have a romantic relationship, with rankorder and classifying judgment methods. This study was conducted to describe current situation 
without changing or influencing facts or without generalizing it to the population. Hence it is a single survey study. In this research model, variables such as the case in question, subject, individual etc. are described separately (Karasar, 2016).

\subsection{Study Group}

Study group was determined using one of the non-random sampling methods, convenience sampling method which aims to save time, money and labor force, on a volunteer basis (Büyüköztürk et al., 2017). Analyses were carried out based on the responses of 255 people, as 4 of 259 stated that they had no relationship before. Information related to the study group is given in Table 1.

Table 1. Demographics of Study Group

\begin{tabular}{|c|c|c|c|c|c|c|c|c|c|c|}
\hline \multirow{3}{*}{ Gender } & \multicolumn{8}{|c|}{ Relationship Status } & & \\
\hline & \multicolumn{2}{|c|}{ Married } & \multicolumn{2}{|c|}{ Engaged } & \multicolumn{2}{|c|}{$\begin{array}{c}\text { In a romantic } \\
\text { relationship }\end{array}$} & \multicolumn{2}{|c|}{$\begin{array}{c}\text { No relationship at } \\
\text { present }\end{array}$} & \multicolumn{2}{|c|}{ Total } \\
\hline & Frequencs & $\%$ & Frequency & $\%$ & Frequency & $\%$ & Frequency & $\%$ & Frequency & $\%$ \\
\hline Male & 49 & 51.04 & 2 & 2,08 & 19 & 19,79 & 26 & 27,08 & 96 & 100,00 \\
\hline Female & 87 & 54,72 & 3 & 1,89 & 36 & 22,64 & 33 & 20,75 & 159 & 100,00 \\
\hline Total & 136 & 53,33 & 5 & 1,96 & 55 & 21,57 & 59 & 23,14 & 255 & 100,00 \\
\hline
\end{tabular}

Table 1 shows that $96(37.65 \%)$ out of 255 people in the study group are males and 159 $(62.35 \%)$ out of 255 people are females. 59 (23..14\%) people have stated that they have no relationship at present though they have had one before. $136(53.33 \%)$ people have said that they are married, $5(1.96 \%)$ people said they are engaged and $55(21.57 \%)$ have said that they are in a romantic relationship.

\subsection{Data Collection Tools}

Two different forms developed by the researchers were used to collect data. 17 people were given the instruction "you are supposed to specify at which situations you get angry considering your relationship", and 81 items were developed in total. When these items were examined, it was discovered that some items were the same or they were similar to each other. Number of items was reduced to 57 by the researchers. Then expert opinions were consulted to academicians one of whom was from psychological counseling and guidance department and the other was from measurement and evaluation department, and 23 sample case items and 6 mood-state items were decided to use. Items were revised in accordance with experts' suggestions of revision about short and clear expression. Hence, mood-state form consisting of 6 items (Form A) and sample case form consisting of 23 items (Form B) were created. Afterwards, Principal Component Analysis (PCA) was performed to determine the dimentionality of the forms. The analysis of Form A consisting of 6 stimulants was carried out by using polycoric correlation in FACTOR 10.9.02 program and analysis of Form B consisting of 23 stimulants using Pearson correlation in SPSS 25 program. The results of PCA for both scales determined to be unidimensional are given in Appendix A and B. Unidimensional structures were confirmed by Parallel analysis results calculated by FACTOR 10.9.02 program and Monte Carlo PCA Program by Marley W. Watkins.

\subsection{Data Analysis}

In the first step in which Form A was given to 255 observers and they were asked to rank between 1 and 6 according to their priorities, scale values $\left(\mathrm{S}_{\mathrm{j}}\right)$ were obtained by using ratios that were calculated according to observers' rank-order judgments to 6 stimulants (scale items). Rank-order judgment is a scaling type whose validity is quite high because it enables to make the biggest discrimination between stimulants (Turgut \& Baykul, 1992; Anıl \& İnal, 2017). 
Frequency matrix was created by using the sequence numbers $(1=$ the least anger eliciting mood-state, $\ldots 6=$ the most anger eliciting mood-state, reserve coding was performed during data analysis) that were given by the participants to anger mood-state items in Form A. Afterwards, pair comparison of each stimulant was made with other stimulants except for the stimulant itself by using the formula below, and frequency matrix was created for each stimulant.

$$
n\left(S_{j i}>S_{k i}\right)=f_{j i} \cdot\left(f_{k<i}+\frac{1}{2} \cdot f_{k i}\right)
$$

$\mathrm{j}, \mathrm{k}$ : stimulants' numbers

i: value given in ranking

$f_{j i}$ : the number of $r_{i}$ sequence value given to $U_{j}$ stimulant

$f_{k i}$ : the number of $r_{i}$ sequence value given to $U_{k}$ stimulant

To create proportion matrix $(\mathrm{P})$, an upper triangular matrix is created by dividing column sums of each stimulant to $\mathrm{N}^{2}$; a lower triangular matrix is obtained by subtracting these values from 1. The Z standard values of the values of P matrix's each element is obtained and by means of them $\mathrm{Z}$ unit normal deviations matrix is created. Mean column values of this matrix give $\mathrm{Sj}$ scale values. Sc scale values are calculated by shifting $\mathrm{Sj}$ values in a way that the smallest $\mathrm{Sj}$ value is 0 (Albayrak Sar1 \& Gelbal, 2015). This process was carried out by Microsoft Excel 2013 program.

In the second step, 23 items in form B were given to 255 observers and they were asked to classify the items between 1 and 4 according to their anger level. There are some assumptions in the law of classifying judgment since they are asked to explain which sequence classes the stimulants belong to.

1- The structure can be divided into limited number of classes.

2- The boundary of any class is not an unmarried point, but a distribution that is called the distribution of boundary judgments.

3- When the observer chooses a class to put the stimulant in, the value of the stimulant is below the boundary value of that class (Turgut \& Baykul, 1992). General formula of the law of rank-order judgment is as follows:

$$
t_{g}-S_{j}=z_{j g} \cdot \sqrt{\sigma_{j}^{2}+\sigma_{g}^{2}-2 \cdot r_{j g} \cdot \sigma_{j} \cdot \sigma_{g}}
$$

$t_{g}$ : mean value of $\mathrm{g}$ boundary point

$\sigma_{g}:$ Standard deviation of observers' judgment belongs to g boundary

$\sigma_{j}$ : Standard deviation of observers' judgments belongs to Uj stimulant

$r_{j g}$ : The correlation between the perceived values of $g$ boundary and $\mathrm{Uj}$ stimulant

$z_{j g}$ : Unit normal deviation of the ratio of number of placing $\mathrm{g}$ boundary that belongs to

Uj stimulant into a lower boundary.

A frequency matrix is created by using the anger levels (1=little,...4=very) determined by the participants when they are exposed to anger-eliciting sample cases in form B, and then cumulative frequency matrix is obtained based on the columns. By dividing the elements of this matrix by the number of people, cumulative ratio matrix is obtained; by calculating $\mathrm{z}$ standard value of each element $Z$ unit normal deviations matrix is obtained, and row means of this matrix are calculated. Through the graphics of lines $y=m x+n$ drawn by using successive rows of $z$ matrix, $m$ and $n$ values and aj and sj values are found out. By using these values scale values are calculated through the means of tg boundary values, and then Sc scale values are calculated by shifting $\mathrm{Sj}$ values in a way that the smallest $\mathrm{Sj}$ value is 0 . In this method, aj and $\mathrm{Sj}$ values 
are obtained by means of graphics (An1l \& İnal, 2017). This process was carried out by Microsoft Excel 2013 program as well.

\section{FINDINGS}

In this section, findings and comments are given related to scaling of data separately with the laws of rank-order and classifying judgment. Data was collected by using forms A and B, which were developed for the purpose of determining the situations causing anger in a relationship.

\subsection{Form A: Rank-Order Judgment Scaling}

In this part, findings related to first and second research problems are given.

\subsubsection{Findings related to first research problem}

In this section mood-states causing anger in 255 people's (observers) relationships are scaled with rank-order judgment and scaling was performed for all participants and then for female and male participants separately.

Table 2. Ranking of Mood-States Causing Anger According to Females, Males and All Participants

\begin{tabular}{llcccccc}
\hline & & \multicolumn{2}{c}{$\begin{array}{c}\text { All participants } \\
(\mathrm{N}=255)\end{array}$} & \multicolumn{2}{c}{$\begin{array}{c}\text { Males } \\
(\mathrm{N}=96)\end{array}$} & \multicolumn{2}{c}{$\begin{array}{c}\text { Females } \\
(\mathrm{N}=159)\end{array}$} \\
\hline & Stimulants & $\begin{array}{c}\text { Stimulant } \\
\text { ranks }\end{array}$ & $\begin{array}{c}\text { Scale } \\
\text { value }\end{array}$ & $\begin{array}{c}\text { Stimulant } \\
\text { ranks }\end{array}$ & $\begin{array}{c}\text { Scale } \\
\text { value }\end{array}$ & $\begin{array}{c}\text { Stimulant } \\
\text { ranks }\end{array}$ & $\begin{array}{c}\text { Scale } \\
\text { value }\end{array}$ \\
\hline A & Unfair treatment & 1 & 0.000 & 1 & 0.000 & 1 & 0.000 \\
B & Being criticized & 6 & 1.148 & 6 & 1.173 & 6 & 1.137 \\
C & Being neglected & 4 & 0.580 & 5 & 0.663 & 4 & 0.532 \\
D & Arrogance & 5 & 0.787 & 4 & 0.564 & 5 & 0.927 \\
E & Humiliation & 2 & 0.232 & 2 & 0.210 & 2 & 0.245 \\
F & Mistrust & 3 & 0.466 & 3 & 0.334 & 3 & 0.546 \\
\hline
\end{tabular}

Table 2 shows that females, males and all participants get angry most at being treated unfairly and they get angry least at being criticized. Furthermore, it is seen that rankings of anger related to mistrust and humiliation are the same for females, males and all participants. Anger levels of females and males to related mood-states are given below.

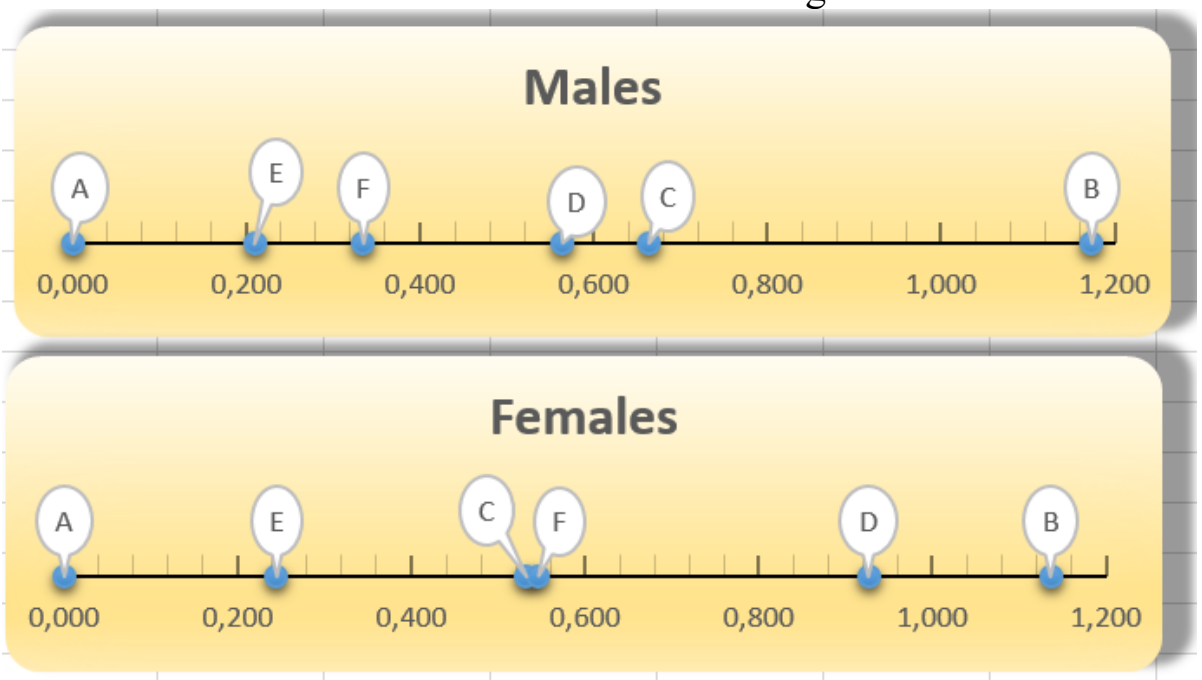

Figure 1. Anger levels of females and males to 6 mood-states

Figure 1 demonstrates that females get angry more than males about worthlessness, and males get angry more than females about arrogance. When the mood-states causing anger were ranked between males and females, the most differentiating mood-state was arrogance. 


\subsubsection{Findings related to second research problem}

In addition to this analysis, participants' anger-eliciting mood-states were examined in terms of their marital status. Table 3 shows that married and unmarried participants get angry most at being treated unfairly, and they get angry least at being criticized. Furthermore, it is seen that the order of anger of married and unmarried people is the same in 'arrogance' and 'humiliation'. Anger levels of married and unmarried participants in related mood-states are shown below.

Table 3. Ranking of Mood-States Causing Anger According to Participants' Marital Status

\begin{tabular}{llcccc}
\hline & & \multicolumn{2}{c}{$\begin{array}{c}\text { Married } \\
(\mathrm{N}=136)\end{array}$} & \multicolumn{2}{c}{$\begin{array}{c}\text { Unmarried } \\
(\mathrm{N}=119)\end{array}$} \\
\hline & Stimulants & Stimulant ranks & Scale value & Stimulant ranks & Scale value \\
\hline A & Unfair treatment & 1 & 0.000 & 1 & 0.000 \\
B & Being criticized & 6 & 1.244 & 6 & 1.047 \\
C & Being neglected & 3 & 0.657 & 4 & 0.500 \\
D & Arrogance & 5 & 0.900 & 5 & 0.666 \\
E & Humiliation & 2 & 0.386 & 2 & 0.062 \\
F & Mistrust & 4 & 0.681 & 3 & 0.228 \\
\hline
\end{tabular}

Figure 2 shows that unmarried participants get angry more at mistrust whereas married participants get angry more at being neglected. It was found that when the mood-states causing anger were ranked between married and unmarried, the most differentiating mood-state was mistrust. Unmarried participants stated that they got angry at mistrust more.

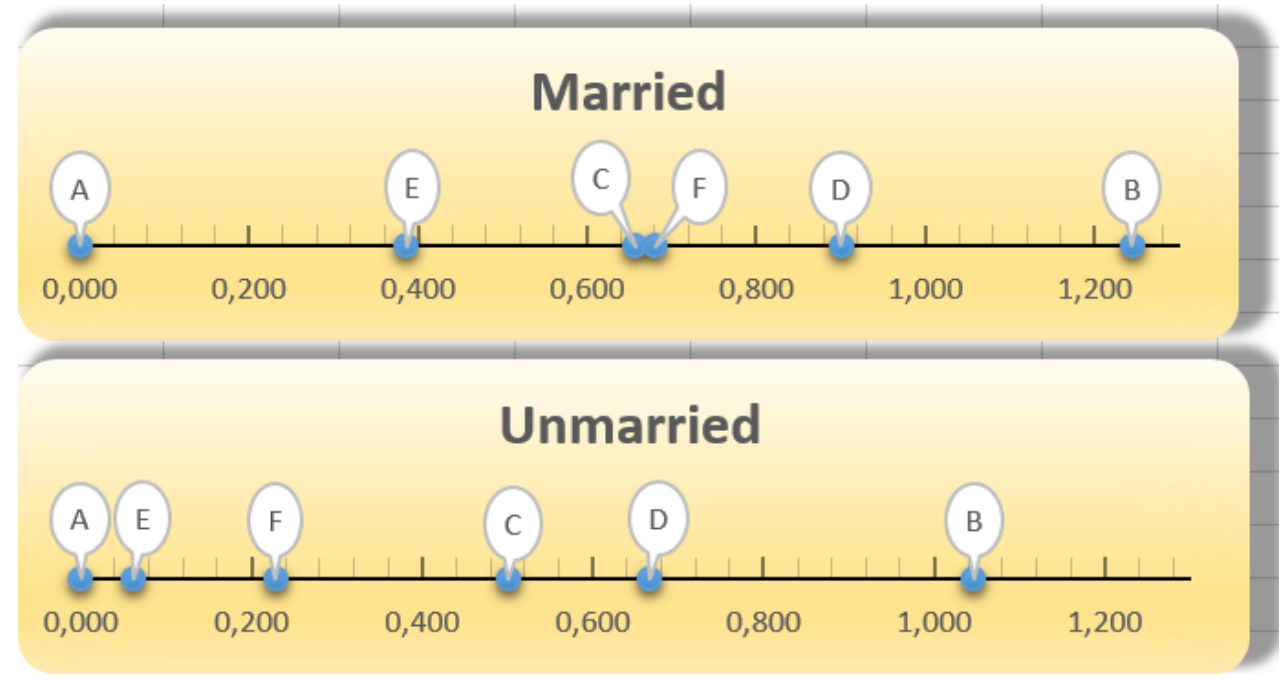

Figure 2. Anger levels of married and unmarried participants to 6mood-states

\subsection{Form B: Classifying Judgment Scaling}

In this part, findings related to third and fourth research problems are given.

\subsubsection{Findings related to third research problem}

This section includes sample cases that are scaled with classifying judgment and cause anger in 255 people's (observers) relationships. Scaling was performed for all participants and then for female and male participants separately. 
Table 4. Classification of Sample Cases Causing Anger According to Females, Males and All Participants

\begin{tabular}{|c|c|c|c|c|c|c|c|}
\hline & \multirow[b]{2}{*}{ Stimulants } & \multicolumn{2}{|c|}{$\begin{array}{l}\text { All } \\
\text { participants } \\
(\mathrm{N}=255)\end{array}$} & \multicolumn{2}{|c|}{$\begin{array}{l}\text { Males } \\
(\mathrm{N}=96)\end{array}$} & \multicolumn{2}{|c|}{$\begin{array}{l}\text { Females } \\
(\mathrm{N}=159)\end{array}$} \\
\hline & & $\begin{array}{l}\text { Sti. } \\
\text { ranks }\end{array}$ & $\begin{array}{l}\text { Scale } \\
\text { value }\end{array}$ & $\begin{array}{l}\text { Sti. } \\
\text { ranks }\end{array}$ & $\begin{array}{l}\text { Scale } \\
\text { value }\end{array}$ & $\begin{array}{l}\text { Sti. } \\
\text { ranks }\end{array}$ & $\begin{array}{l}\text { Scale } \\
\text { value }\end{array}$ \\
\hline 1 & $\begin{array}{l}\text { Not behaving according to etiquette (go on a visit } \\
\text { empty-handed, to talk about politics everywhere, } \\
\text { oratory etc.) }\end{array}$ & 18 & 0.418 & 16 & 0.374 & 19 & 0.446 \\
\hline 2 & Ignoring the issues that I care about & 4 & 1.012 & 5 & 0.888 & 4 & 1.105 \\
\hline 3 & $\begin{array}{l}\text { Making the things that s/he does not want me to } \\
\text { do }\end{array}$ & 3 & 1.037 & 3 & 1.165 & 6 & 0.970 \\
\hline 4 & Making decisions without consulting me & 8 & 0.879 & 4 & 0.991 & 11 & 0.815 \\
\hline 5 & Being extremely jealous of me & 19 & 0.407 & 12 & 0.516 & 20 & 0.343 \\
\hline 6 & Not trusting me & 2 & 1.258 & 2 & 1.278 & 2 & 1.250 \\
\hline 7 & $\begin{array}{l}\text { Making huge amount of expenses without my } \\
\text { knowledge }\end{array}$ & 15 & 0.494 & 14 & 0.419 & 17 & 0.534 \\
\hline 8 & Trying to impose his/her ideas on me & 9 & 0.750 & 11 & 0.540 & 10 & 0.890 \\
\hline 9 & $\begin{array}{l}\text { Not being able to talk about any issue without a } \\
\text { fight }\end{array}$ & 7 & 0.884 & 6 & 0.873 & 9 & 0.894 \\
\hline 10 & $\begin{array}{l}\text { Being extremely connected to the gender roles } \\
\text { (women do the cleaning, men earn money, men } \\
\text { do not cry etc.) }\end{array}$ & 14 & 0.647 & 21 & 0.153 & 7 & 0.946 \\
\hline 11 & $\begin{array}{l}\text { Behaving in an extremely calm and slow manner } \\
\text { even in emergency work }\end{array}$ & 16 & 0.487 & 18 & 0.305 & 16 & 0.604 \\
\hline 12 & Underestimating what I have done & 5 & 1.006 & 7 & 0.722 & 3 & 1.185 \\
\hline 13 & Seeking for praise and tolerance all the time & 21 & 0.253 & 17 & 0.327 & 22 & 0.210 \\
\hline 14 & $\begin{array}{l}\text { Making unnecessary and offending comments } \\
\text { about my family }\end{array}$ & 1 & 1.295 & 1 & 1.291 & 1 & 1.303 \\
\hline 15 & Mess (socks, clothes etc.) & 22 & 0.252 & 19 & 0.256 & 21 & 0.251 \\
\hline 16 & $\begin{array}{l}\text { Being a fan of any subject (Team, political party } \\
\text { etc.) }\end{array}$ & 23 & 0.000 & 23 & 0.000 & 23 & 0.000 \\
\hline 17 & Having a harsh speaking style & 12 & 0.679 & 10 & 0.549 & 14 & 0.751 \\
\hline 18 & $\begin{array}{l}\text { Showing me as the bad cop when setting rules for } \\
\text { the children }\end{array}$ & 20 & 0.367 & 22 & 0.074 & 18 & 0.529 \\
\hline 19 & Not keeping his/her words on time & 11 & 0.744 & 13 & 0.441 & 8 & 0.926 \\
\hline 20 & Being disrespectful towards my spare time & 10 & 0.747 & 8 & 0.703 & 13 & 0.778 \\
\hline 21 & $\begin{array}{l}\text { Spending too much time with technological } \\
\text { devices or social environment }\end{array}$ & 17 & 0.482 & 20 & 0.182 & 15 & 0.642 \\
\hline 22 & Failing to fulfill his/her responsibilities & 6 & 0.908 & 9 & 0.682 & 5 & 1.044 \\
\hline 23 & Sharing the tasks unfairly & 13 & 0.649 & 15 & 0.408 & 12 & 0.782 \\
\hline
\end{tabular}

Table 4 shows that males, females and all participants get angry most when unnecessary and offending comments are made about their families. They get angry least about the situation that their partners are fan of any subject (team, political party etc.). Second situation they get angry most is mistrust. Anger levels of females and males to related sample cases are shown below. Figure 3 illustrates that females get angry more than males at the sample cases "trying to impose his/her ideas on me", "being extremely connected to the gender roles (women do the cleaning, men earn money, men do not cry etc.)", "behaving in an extremely calm and slow manner even in emergency work", "underestimating what I have done", "not keeping his/her words on time", "spending too much time with technological devices or social environment", "failing to fulfill his/her responsibilities", "sharing the tasks unfairly". It can be stated that males get angry more than females at the sample cases "not behaving according to etiquette (go on a visit emptyhanded, to talk about politics everywhere, oratory etc.)", "making the things that s/he does not want me to do", "making decisions without consulting me", "making extreme jealousy", 
"making huge amount of expenses without my knowledge", "not being able to talk about any issue without a fight"," seeking for praise and tolerance all the time", "mess (socks, clothes etc.)"," having a harsh speaking style"," being disrespectful towards my spare time". It was concluded that when the sample cases causing anger were ranked between males and females, the most differentiating sample case was "being extremely connected to the gender roles (women do the cleaning, men earn money, men do not cry etc.)". Females stated that they got angry at this sample case more.
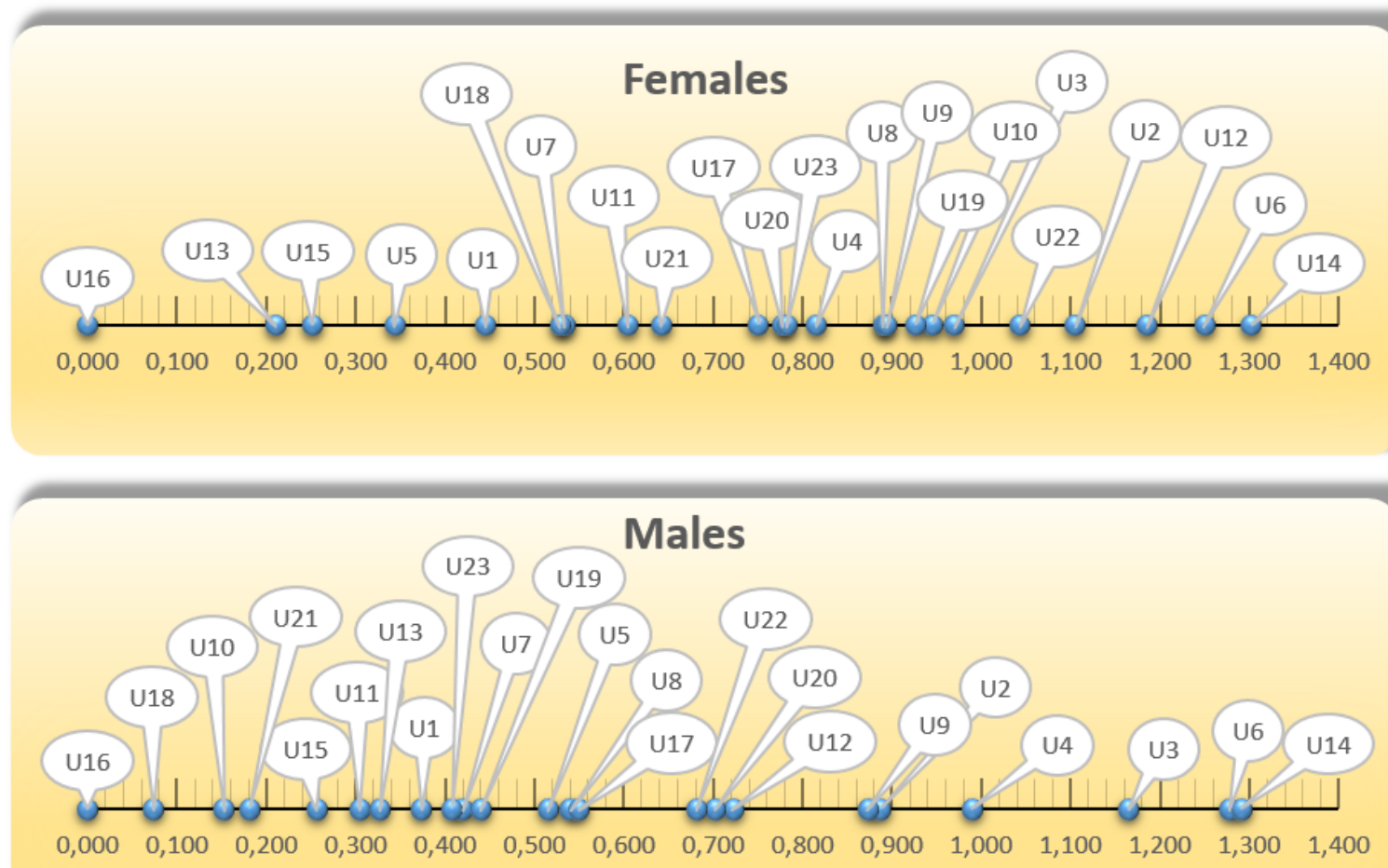

Figure 3. Anger levels of females and males to 23 sample cases

\subsubsection{Findings related to third research problem}

In addition to this analysis, participants' anger-eliciting sample cases were examined in terms of their marital status. Table 5 reveals that married participants get angry most at the sample case "ignoring the issues that I care about" and unmarried participants get angry most at "making unnecessary and offending comments about my family". It was also found that both groups got angry least at the sample case "being a fan of any subject (Team, political party etc.)". It appears that rankings of anger related to sample cases "not trusting me", "spending too much time with technological devices or social environment", "being disrespectful towards my spare time" and "sharing the tasks unfairly" are the same for married and unmarried participants. Anger levels of married and unmarried participants to related sample cases are shown below. 
Table 5. Classification of Sample Cases Causing Anger According to Participants' Marital Status

\begin{tabular}{|c|c|c|c|c|c|}
\hline & \multirow[b]{2}{*}{ Stimulants } & \multicolumn{2}{|c|}{$\begin{array}{l}\text { Married } \\
(\mathrm{N}=136)\end{array}$} & \multicolumn{2}{|c|}{$\begin{array}{l}\text { Unmarried } \\
(\mathrm{N}=119)\end{array}$} \\
\hline & & $\begin{array}{l}\text { Sti. } \\
\text { ranks }\end{array}$ & $\begin{array}{l}\text { Scale } \\
\text { value }\end{array}$ & $\begin{array}{l}\text { Sti. } \\
\text { ranks }\end{array}$ & $\begin{array}{l}\text { Scale } \\
\text { value }\end{array}$ \\
\hline 1 & $\begin{array}{l}\text { Not behaving according to etiquette (go on a visit empty-handed, to } \\
\text { talk about politics everywhere, oratory etc.) }\end{array}$ & 18 & 0.344 & 19 & 0.497 \\
\hline 2 & Ignoring the issues that I care about & 1 & 1.004 & 7 & 1.021 \\
\hline 3 & Making the things that $\mathrm{s} /$ he does not want me to do & 6 & 0.711 & 3 & 1.344 \\
\hline 4 & Making decisions without consulting me & 5 & 0.777 & 8 & 1.020 \\
\hline 5 & Making extreme jealousy & 19 & 0.238 & 15 & 0.667 \\
\hline 6 & Not trusting me & 2 & 1.003 & 2 & 1.506 \\
\hline 7 & Making huge amount of expenses without my knowledge & 12 & 0.581 & 20 & 0.375 \\
\hline 8 & Trying to impose his/her ideas on me & 7 & 0.683 & 12 & 0.845 \\
\hline 9 & Not being able to talk about any issue without a fight & 11 & 0.618 & 5 & 1.146 \\
\hline 10 & $\begin{array}{l}\text { Being extremely connected to the gender roles (women do the } \\
\text { cleaning, men earn money, men do not cry etc.) }\end{array}$ & 15 & 0.469 & 9 & 0.963 \\
\hline 11 & work & 16 & 0.461 & 18 & 0.505 \\
\hline 12 & Underestimating what I have done & 3 & 0.859 & 4 & 1.182 \\
\hline 13 & Seeking for praise and tolerance all the time & 22 & 0.137 & 21 & 0.343 \\
\hline 14 & Making unnecessary and offending comments about my family & 4 & 0.800 & 1 & 2.018 \\
\hline 15 & Mess (socks, clothes etc.) & 20 & 0.218 & 22 & 0.265 \\
\hline 16 & Being a fan of any subject (Team, political party etc.) & 23 & 0.000 & 23 & 0.000 \\
\hline 17 & Having a harsh speaking style & 9 & 0.638 & 14 & 0.735 \\
\hline 18 & Showing me as the bad cop when setting rules for the children & 21 & 0.210 & 16 & 0.570 \\
\hline 19 & Not keeping his/her words on time & 14 & 0.514 & 11 & 0.919 \\
\hline 20 & Being disrespectful towards my spare time & 10 & 0.628 & 10 & 0.920 \\
\hline 21 & $\begin{array}{l}\text { Spending too much time with technological devices or social } \\
\text { environment }\end{array}$ & 17 & 0.431 & 17 & 0.530 \\
\hline 22 & Failing to fulfill his/her responsibilities & 8 & 0.679 & 6 & 1.131 \\
\hline 23 & Sharing the tasks unfairly & 13 & 0.568 & 13 & 0.782 \\
\hline
\end{tabular}

Figure 4 shows that while married participants get angry at the sample cases "not behaving according to etiquette (go on a visit empty-handed, to talk about politics everywhere, oratory etc.)", "ignoring the issues that I care about", "making decisions without consulting me", "making huge amount of expenses without my knowledge", "trying to impose his/her ideas on me", "mess (socks, clothes etc.)", "underestimating what I have done" and "having a harsh speaking style" more than unmarried participants; unmarried participants get angry at the sample cases "making the things that s/he does not want me to do", "making extreme jealousy", "not being able to talk about any issue without a fight", "being extremely connected to the gender roles (women do the cleaning, men earn money, men do not cry etc.)", "seeking for praise and tolerance all the time", "making unnecessary and offending comments about my family", "not keeping his/her words on time" and "failing to fulfill his/her responsibilities" more than married participants. It was found that when the sample cases causing anger were ranked between married and unmarried participants, the most differentiating sample case was "making huge amount of expenses without my knowledge". Married participants stated that they got angry at this sample case more. 


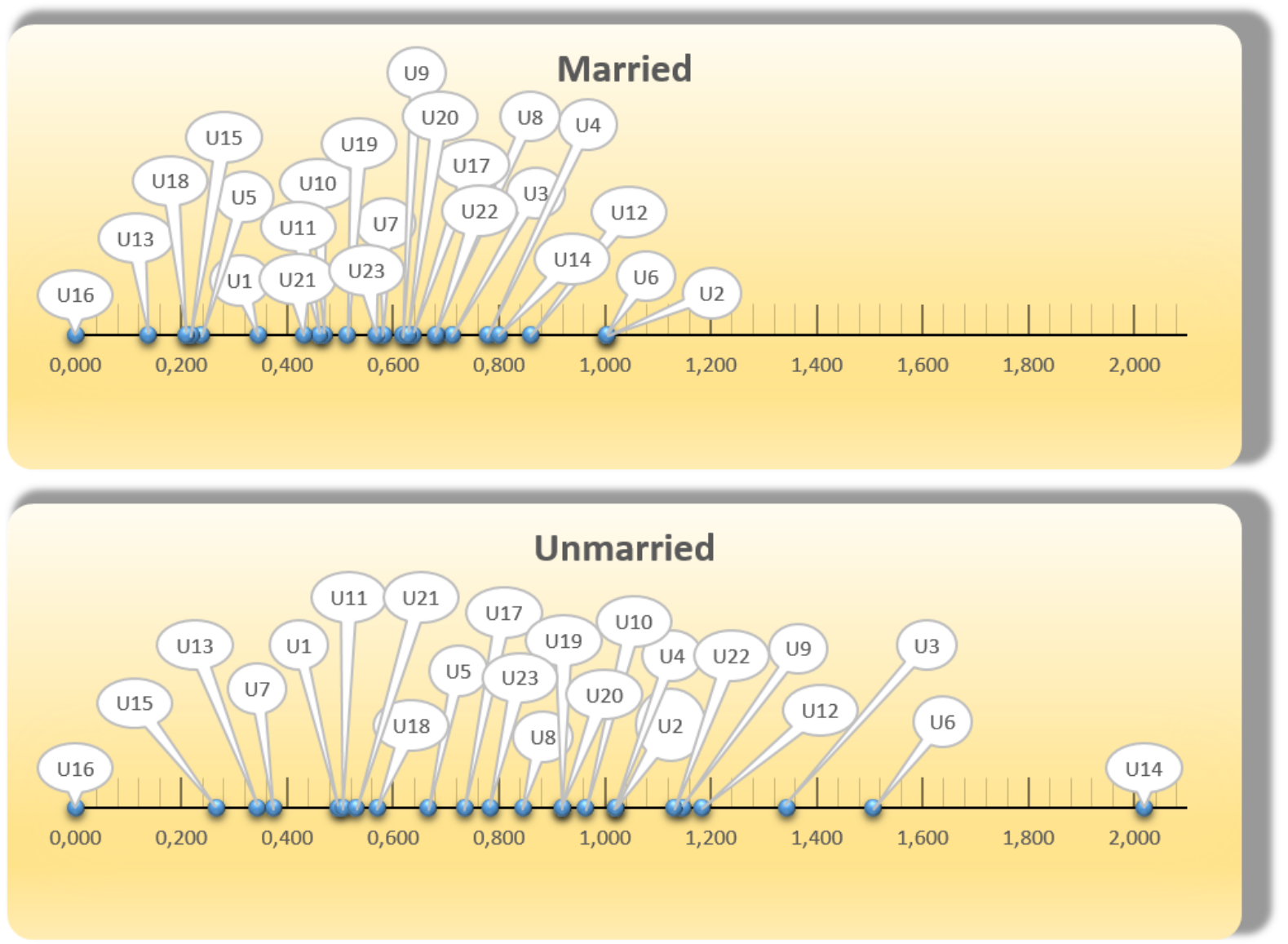

Figure 4. Anger levels of married and unmarried participants to 23 sample cases

\section{DISCUSSION and CONCLUSION}

In this study, the law of classifying judgment scaling was used for 6 items, and the law of rankorder judgment scaling was used for 23 items. Although the fact that judgments can be fully differentiated from each other in pair wise comparisons increases the consistency, it would be more useful to rank stimulants instead of this comparison as the number of items increases. As the number of items increases ranking would be more difficult and classification becomes more appropriate. Furthermore, differentiation of scale values with respect to which scaling method judge's decisions are obtained makes the method to be used important (Turgut \& Baykul, 1992). Apart from the result of the study that Balkaya (2001) conducted to reveal the differences/resemblances between anger and furiousness, this study aims to identify the reasons of anger which is one of the basic feelings in relationships. First, participants were asked to rank anger-eliciting mood-states between 1 and 6 from the most anger-eliciting mood-state to the least anger-eliciting one, and it was seen that regardless of their gender and marital status participants got angry most at unfair treatment, and they got angry least at being criticized. This may be associated with the fact that majority of the study group is composed of individuals whose education level is high and who are active working people; because it is likely that the people who are in communication with more than one person perceive criticism constructively.

Although there is no differentiation in the first two mood-states in terms of gender, the fact that females get angry at being neglected more than males, and males get angry at insensitivity, arrogance and mistrust more than females indicates that females get angry at general situations like not meeting their expectations, and males get angry at general situations like not being taken seriously. The fact that males get angry considerably at arrogance compared with females supports this result. In scale development study of Balkaya \& Şahin (2003), situations causing anger are restricted to not being taken seriously, being treated unfairly and being criticized. 
Likewise, even rankings of anger related to unfair treatment, humiliation, arrogance, being criticized are the same with regard to the marital status, it has been stated that married participants get angry more at being neglected while unmarried participants get angry more at mistrust. It is considered that there are differences due to the time spent together and interaction. These results correspond to results obtained by Kaynak (2014) even though the methods used are different.

Secondly, participants were asked to classify their anger at anger-eliciting sample cases between 1 and 4 from less to more. It was concluded that regardless of their gender and marital status all participants got angry least at the sample case" being a fan of any subject (Team, political party etc.)" and except for married participants they got angry most at sample case "making unnecessary and offending comments about my family". It was seen that married participants got angry most at the sample case "ignoring the issues that I care about". It is likely that this situation differs in married participants because of the expectation that in order to enjoy the time spent together, individual tastes should also be close to each other.

When sample cases are examined, the fact that females get angry more than males at the sample cases "trying to impose his/her ideas on me", "being extremely connected to the gender roles (women do the cleaning, men earn money, men do not cry etc.)", "underestimating what I have done" and "sharing the tasks unfairly" can be seen as a differentiation of anger levels of these cases with gender roles together with culture. The fact that females and males give the most differentiating reaction to sample case "being extremely connected to the gender roles (women do the cleaning, men earn money, men do not cry, etc.)" supports this judgment. It can be reported that it is also similar to Özmen Süataç (2010)'s idea that anger and reactions to anger should be treated as individual differences.

Similarly, even if rankings of anger related to sample cases "not trusting me", "spending too much time with technological devices or social environment", "being disrespectful towards my spare time" and "sharing the tasks unfairly "are the same in terms of the marital status; married participants stated that they got angry more at sample cases "not behaving according to etiquette (go on a visit empty-handed, to talk about politics everywhere, oratory etc.)", "ignoring the issues that I care about", "making decisions without consulting me", "making huge amount of expenses without my knowledge", "trying to impose his/her ideas on me", "underestimating what I have done", "mess (socks, clothes etc.)" and "having a harsh speaking style". Unmarried participants explained that they got angry more at sample cases "making the things that $\mathrm{s} / \mathrm{he}$ does not want me to do", "making extreme jealousy", "not being able to talk about any issue without a fight", "being extremely connected to the gender roles (women do the cleaning, men earn money, men do not cry etc.)", "seeking for praise and tolerance all the time", "making unnecessary and offending comments about my family", "not keeping his/her words on time" and "failing to fulfill his/her responsibilities". It is considered that there are differences due to the time spent together and interaction as well. Similar to the studies of Erok (2013) and Togay (2016), the fact that the most differentiating sample case is "making huge amount of expenses without my knowledge" is considered to be associated with common investments such as common budget or being aware of the expenses in marriage.

Considering the results of this study, in order to protect family unity which is the most basic unit of the society and establish it in an appropriate way, it is recommended to conduct mixed researches to investigate the possible causes of anger mentioned above. In addition, it is suggested that crime prevention studies should be performed by developing awareness programs aimed at understanding the reasons behind anger. Comparisons of different scaling methods calculated on the same stimulants are also recommended. 


\section{Declaration of Conflicting Interests and Ethics}

The authors declare no conflict of interest. This research study complies with research publishing ethics. The scientific and legal responsibility for manuscripts published in IJATE belongs to the author(s).

\section{ORCID}

Merve YILDIRIM SEHERYELI (D) https://orcid.org/0000-0002-1106-5358

Duygu ANIL (iD https://orcid.org/0000-0002-1745-4071

\section{REFERENCES}

Acar Güvendir, M., \& Özer Özkan, Y. (2013). A comparison of two scaling methods: Pair wise comparison and rank-order judgments scaling. Journal of Educational Sciences Research, 3(1), 105-119.

Albayrak Sarı, A., \& Gelbal, S. (2015). A Comparison of Scaling Procedures Based on PairWise Comparison and Rank-Order Judgments Scaling. Journal of Measurement and Evaluation in Education and Psychology, 6(1), 126-141.

Anıl, D., \& Güler, N. (2006). An example of the scaling study by pair-wise comparison method. Hacettepe University Journal of Education, 30, 30-36.

Anıl, D., \& İnal, H. (2017). Psikofizikte ölçekleme uygulamaları. Ankara: Pegem Akademi.

Balkaya, F. (2001). The Development of multidimensional anger inventory and effect on some syptom groups. Unpublished MA Thesis. Ankara University, Graduate School of Social Sciences, Ankara.

Balkaya, F., \& Şahin, N. H. (2003). Multidimensional Anger Scale. Turkish Journal of Psychiatry, 3, 192-202.

Bozgeyikli, H., Toprak, E., \& Derin, S. (2016). Teacher candidates' career values perceptions by rank order judgments scaling. HAK-IŞ International Journal of Labor and Society, 5(11), 204-225.

Bülbül, S., \& Köse, A. (2010). Examining between regional internal migration movements in Turkey with multidimensional scaling. Istanbul University Journal of the School of Business Administration, 39(1).

Büyüköztürk, Ş., Kılıç Çakmak, E., Akgün, Ö. E., Karadeniz, Ş., \& Demirel, F. (2017). Bilimsel araştırma yöntemleri. Ankara: Pegem Akademi.

Crocker, L., \& Algina, J. (2006).Introduction to classical and modern test theory. USA: Cengage Learning.

Demirus, K. B., \& Gelbal, S. (2020) Scaling of Students' Instructional Techniques Preferences used in Science Lessons. Kastamonu Education Journal, 28(1), 154-170.

Erdoğdu, M. (2018). Relationship between early maladaptive childhood schemas with trait anger and anger expressions. Unpublished MA Thesis. Ankara University, Graduate School of Health Sciences, Ankara.

Erok, M. (2013). Interpersonal cognitive distortions, relationship beliefs, interpersonal anger, interpersonal relationship, problem solving and marital conflict. Master Thesis. Maltepe University, Graduate School of Social Sciences, İstanbul.

Güler, N., \& Anıl, D. (2009). Scaling through pair-wise comparison method in required characteristics of students applying for post graduate programs. International Journal of Human Sciences, 6(1), 627-639.

Güvendir, M., \& Özkan, Y. (2013). A comparison of two scaling methods: Pair wise comparison and rank-order judgments scaling. Journal of Educational Sciences Research, 3(1), 105119.

Karasar, N. (2016). Bilimsel araştırma yöntemi. Ankara: Nobel Yayıncılık.

Kassinove, H., \& Suckodolsky, D. (1995). Anger disorders: basic science and practice issues. 
Issues in Comprehensive Pediatric Nursing, 18, 173-205.

Kırkök, F. (2017). The relationship between the levels of depression, alexithymia and anger of the individuals who have divorced and non-divorced parents. Unpublished MA Thesis. Üsküdar University, Graduate School of Social Sciences, İstanbul.

Özkan, M., \& Arslantaş, H. İ. (2013). A study of scaling with ranking judgment method on characteristic of effective teacher. Trakya University, Journal of Social Sciences, 15(1), 311-330.

Özmen Süataç, A. (2010). Marital adjustment research in terms of interpersonal style and anger. Master Thesis. Ege University, Graduate School of Health Sciences, İzmir.

Satıc1, S. A. (2014). Anger Rumination Scale: Psychometric properties of the Turkish version. Anatolian Journal of Psychiatry, 15, 328-334.

Sayın, A., \& Gelbal, S. (2014). Başarıyı Etkileyen Faktörlerin Önem Derecelerinin Ardışık Aralıklar Yöntemiyle Ölçeklenmesi. Amasya Üniversitesi, Eğitim Fakültesi Dergisi, $3(1), 1-26$.

Soykan, Ç. (2013). Öfke ve öfke yönetimi. Kriz dergisi, 11(2), 19-27.

Tezbaşaran, E. (2017). Scaling types of test with the method of absolute judgement and assessing them with The students' views. HAYEF Journal of Education, 14(1), 143-162.

Togay, A. (2016). Relations between self concealment, anger expression style and authenticity in married persons. Unpublished MA Thesis. Hacettepe University, Graduate School of Educational Sciences, Ankara.

Turgut, M. F., \& Baykul, Y. (1992). Ölçekleme teknikleri. Ankara: ÖSYM Yayınları.

Tüzüntürk, S. (2009). Çok boyutlu ölçekleme analizi: suç istatistikleri üzerine bir uygulama. Uludağ Üniversitesi İktisadi ve İdari Bilimler Fakültesi Dergisi, 28(2), 7191.

Uğurcan, B. (2018). Stress, depression, anxiety and alexithymia in psoriasis. Master Thesis. İstanbul Bilim University, Graduate School of Social Sciences, İstanbul.

Yapabaş, S. İ. (2018). The relationship between eating behaviours, anger and codependency on overweight and obese individuals. Unpublished MA Thesis. Işık University, Graduate School of Social Sciences, İstanbul.

Yaşar, M. (2016). Scaling the features considered to have affected the academic success of teacher candidates on the basis of rank-order judgement scaling technique. Pamukkale University Journal of Education, 40, 274-288.

Y1lmaz Koğar, E., \& Demircioğlu, E. (2016). A Scaling study about 6.-7.-8.grades mathematics learning domain. Başkent University Journal of Education, 3(1), 44-52. 


\section{APPENDIX}

\section{1. Appendix A: Form A}

Table A1. KMO and Bartlett's statistic results

\begin{tabular}{rc}
\hline KMO & 0.639 \\
Bartlett's statistic & 326.1 \\
$\mathrm{p}$ & 0.00 \\
\hline
\end{tabular}

Table A2. Eigenvalues

\begin{tabular}{cccc}
\hline Variables & Eigenvalues & $\begin{array}{c}\text { Proportion of } \\
\text { Variance }\end{array}$ & $\begin{array}{c}\text { Cumulative Proportion } \\
\text { of Variance }\end{array}$ \\
\hline 1 & $2.391^{*}$ & 39.90 & 39.90 \\
2 & 1.026 & 17.11 & \\
3 & 0.912 & 15.23 & \\
4 & 0.706 & 11.80 & \\
5 & 0.676 & 11.32 & \\
6 & 0.288 & 4.81 & \\
\hline
\end{tabular}

*Adviced number of dimention according to Parallel Analysis test results.

Table A3. Factor Loading and Reliability Coefficient

\begin{tabular}{rl}
\hline Variables & F1 \\
\hline 1 & 0.633 \\
2 & 0.564 \\
3 & 0.626 \\
4 & 0.597 \\
5 & 0.684 \\
6 & 0.676 \\
\hline Cronbach Alpha & 0.698 \\
Omega & 0.820 \\
\hline
\end{tabular}




\section{2. Appendix B: Form B}

Table B1. KMO and Bartlett's statistic results

\begin{tabular}{rr}
\hline KMO & 0.887 \\
Bartlett's statistic & 2076.22 \\
$\mathrm{p}$ & 0.00 \\
\hline
\end{tabular}

Table B2. Eigenvalues

\begin{tabular}{cccc}
\hline Variables & Eigenvalues & $\begin{array}{c}\text { Proportion of } \\
\text { Variance }\end{array}$ & $\begin{array}{c}\text { Cumulative Proportion } \\
\text { of Variance }\end{array}$ \\
\hline 1 & $7.578^{*}$ & 32.946 & 32.946 \\
2 & 1.473 & 6.403 & \\
3 & 1.349 & 5.865 & \\
4 & 1.148 & 4.993 & \\
5 & 1.062 & 4.617 & \\
6 & 1.003 & 4.361 & \\
7 & 0.961 & 4.178 & \\
8 & 0.867 & 3.769 & \\
9 & 0.782 & 3.400 & \\
$\ldots$ & & & \\
\hline
\end{tabular}

*Adviced number of dimention according to Parallel Analysis test results.

Table B3. Factor Loading and Reliability Coefficient

\begin{tabular}{cccc}
\hline Variable & F1 & Variable & F1 \\
\hline 1 & 0.743 & 13 & 0.542 \\
2 & 0.728 & 14 & 0.530 \\
3 & 0.723 & 15 & 0.522 \\
4 & 0.701 & 16 & 0.486 \\
5 & 0.680 & 17 & 0.473 \\
6 & 0.677 & 18 & 0.416 \\
7 & 0.648 & 19 & 0.400 \\
8 & 0.636 & 20 & 0.376 \\
9 & 0.623 & 21 & 0.426 \\
10 & 0.603 & 22 & 0.458 \\
11 & 0.557 & 23 & 0.450 \\
12 & 0.547 & & \\
\hline Cronbach & 0.904 & & \\
Alpha & & & \\
\hline
\end{tabular}

